\title{
Confused comment on Warnock
}

\section{The British House of Commons has had a muddled debate about the regulation of in vitro fertilization. The British government should devise more liberal legislation than was urged last week.}

DAME Mary Warnock's report on in vitro fertilization and related matters seems to have had a better reception from the general press than from the British House of Commons, which spent last Friday ( 22 November) debating the issues that had been raised. By legend, this would have been one of those occasions when the British parliament should have been at its best. With nothing to be decided, and with no compulsion on party managers to dragoon their members through some predetermined voting booth (called a "division lobby" at Westminster), Members of Parliament with a philosophical turn of mind should have been free to take a broad view of an important set of issues, giving the government some durable help with the design of the legislation that it is committed to produce. In the event, the discussion was down-at-heel, dominated by complaints that the Warnock Committee failed to define the point in the development of an embryo at which life may be said to begin, by expressions of horror at what people in laboratories were about and by some simple misunderstandings that would be laughable if they were not held by those who will be responsible for whatever legislation eventually emerges.

It is inevitable that liberal opinions should be drowned in such a clamour. Even so, the view that the practice of in vitro fertilization is an important part of the treatment of infertility was strongly put. The case for research with living early embryos was put, but unavoidably made to seem simplistic by the apparent need to make its importance tangible by guessing at what the outcome might be. Surrogate motherhood won only the most tepid advocacy - most people are against it. The House of Commons seemed not to be especially downcast at the reminder (which Warnock vividly provided) that it has done nothing, these past twenty years, to deal with the legal problems occasioned by the now widespread practice of artificial insemination (where, under British law as it stands, such a child is illegitimate and should formally be adopted by its mother's husband, and where Warnock recommended automatic legitimacy but also disclosure of the method of conception at the child's majority). In the circumstances, the most memorable feature of the debate was that those in favour of the proposition that embryos are living persons from the instant of conception included both Mr Ian Paisley, the Ulster Unionist, and Mr John Hume, the leader of the Social Democratic Labour Party in Ulster - inveterate opponents on almost every other issue. The danger only barely concealed by the debate, in which the government promised that it may be possible to find administrative devices for regulating Warnock matters in the spell before legislation can be devised, is that some MP will jump in with a private member's bill drawn so emotively that nobody will dare oppose it.

What the House of Commons should have understood last week, and what the British government must now appreciate, is that there is a world of difference between the novel techniques in human embryology that are already parts of medical practice and the opportunities that have arisen in research. That the use of novel medical techniques should be regulated is not, of course, unusual and is not, in principle, objectionable. In Britain as almost everywhere, both abortion and (further from the clinic) adoption are regulated by law. Warnock asked that those of fering in vitro fertilization should be registered, which is fair; there is also a case for asking that data should be securely logged, on which the committee was ambiguous. The committee also agonized about surrogacy, concluding that the practice is always undesirable but that surrogacy with a commercial element is frankly unacceptable, and must be made illegal. Mr Norman Fowler, the Secretary of State for Social Services, warned those within earshot that surrogacy with payment may already be illegal under the British adoption laws as they stand. But even that argument is not as simple as it sounds, for there is an important difference between what may seem the sale of intact people and the prearrangement of a genetically known birth. Even on this contentious point, the British government should shy away from outright bans, as one of the minority reports of the Warnock Committee asked.

Research is quite a different kettle of fish. The Warnock Committee recommended licensed research with embryos no older than 14 days. The weakness of that position is that the timelimit is arbitrary. Moreover, the case for research on early embryos is necessarily sketchy - it is the old difficulty that people cannot tell what they will find until they look. The sensible course of action for the government to follow is to accept the Warnock proposal for a committee to oversee the conduct of all research projects proposed, much along the lines of the committees that have regulated recombinant DNA research in different places, but with the added proviso that a project should be shown not merely to be harmless but potentially valuable. The time-limit should be dropped. And the proceedings of such a committee should not merely be public but publicized. Then even the House of Commons might understand why the opportunities in this field are exciting and important.

\section{Bettering farm support}

\section{The Reagan administration should give agricultural research its due.}

As the Reagan administration began its curious effort last week to find budget cuts that will eliminate a $\$ 200,000$ million a year deficit without raising taxes, one of its first discoveries was the $\$ 10,000$ million or so spent each year to keep farmers in business. According to the "supply-side" dogma that still seems to grip everyone in the administration (except perhaps David Stockman, director of the Office of Management and Budget), supply creates its own demand; remove restraints on production (that is, government intervention), and everything will work just fine. Hence the not-so-surprising talk of doing away with the 50-yearold strategy of farm price supports in favour of what is being called a "market-oriented" approach.

The Reagan administration is not renowned for its grasp of history, so a quick refresher course on what happened the last time the United States tried laissez faire in farming is perhaps in order. Above all, it is worth remembering that throughout the 1920 s, it was not just US farmers but farmers everywhere who struggled with chronic overproduction. During that decade of booming prosperity for business and industry, the farm economy was deathly ill. The prices of commodities, always subject to cycles of boom and bust, swung dramatically; the price of wheat, for example, fell from $\$ 3$ a bushel to $\$ 0.30$. By 1932, when the depression had finally struck the rest of the economy, the prices farmers received for their crops compared with the prices they had 